\title{
ОСОБЛИВОСТІ КИСЛОТОУТВОРЮВАЛЬНОЇ ФУНКЦІї ШЛУНКА У ХВОРИХ НА ХРОНІЧНИЙ ГАСТРИТ ТА ЦУКРОВИЙ ДІАБЕТ 2 ТИПУ
}

\author{
๑є. С. Сірчак, С. В. Пацкун \\ ДВНЗ «Ужгородський національний університет»
}

РЕзЮМЕ. Через високу захворюваність і смертність від хвороб, викликаних Helicobacter pylori (HР), значні зусилля були спрямовані на визначення точних механізмів, за допомогою яких цей патоген викликає запалення шлунка, оскільки дані механізми не $є$ достатньо дослідженими.

Мета - оцінити особливості кислотоутворювальної функції шлунка у хворих на хронічний гастрит (ХГ) та цукровий діабет (ЦД) 2 типу залежно від наявності чи відсутності Helicobacter pylori.

Матеріал і методи. Обстежено 80 пацієнтів, середній вік яких склав $(57,6 \pm 2,3)$ року. Дане дослідження проводили за участі 45 (56,3 \%) жінок та 35 (43,7 \%) чоловіків. Всі хворі були поділені на дві групи залежно від інфікування Helicobacter pylori. До I групи увійшли 60 (75 \%) осіб, які були НР-позитивними, а другу групу сформовано 3 20 (25\%) осі6 - НР-негативних хворих на ЦД 2 типу та хронічний гастрит.

Результати. У пацієнтів із ЦД 2 типу та ХГ залежно від наявності чи відсутності НР виявлено достовірну різницю між кислотоутворювальною функцією шлунка. Тож пацієнти, які $є$ НР-позитивними, частіше мали порушення кислотоутворювальної функції у вигляді вираженої гіперацидності (68,3%), а пацієнти без НР мали помірну гіперацидність (75\%).

Висновок. У більшості хворих на ЦД 2 типу та ХГ при експрес рН-метрії кислотоутворювальної функції шлунка виявлено гіперацидний стан.

КлючОВІ СлОВА: цукровий діабет 2 типу; хронічний гастрит; Helicobacter pylori.

Вступ. Згідно з еволюційними аналізами, Helicobacter pylori (HP) асоціювали із сучасними людьми принаймні 100000 років після того, як бактерія вперше потрапила до людського організму з невідомого джерела. Протягом цього тривалого часу співіснування НР пристосувалася до імунітету людини, використовуючи різні механізми, тому на сьогодні дану бактерію вважають парадигмою для хронічних інфекцій [1].

Адаптація бактерії до несприятливого впливу кислого рН $\epsilon$ складним процесом, що залежить від бактеріальних факторів (білки, ферменти, форма і джгутики) та факторів навколишнього середовища (сечовина, слиз і кислота) [2].

НР чітко модулює секрецію шлункової кислоти кількома способами. Розвиток гіпо- або гіперхлоргідрії залежить від тривалості інфікування, переважного анатомічного місця інфекції, спектра факторів вірулентності бактерії, генетичних та імунологічних відповідей організму [3].

Для існування у шлунку НР повинна була розробити унікальну реакцію на кислотність для полегшення акліматизації до кислоти. Ця реакція вимагає здатності відчувати зміни в навколишньому/периплазматичному і цитоплазматичному $\mathrm{pH}$, ініціювати швидку й стійку зміну транскрипції відповідних генів. Гени, пов'язані з акліматизацією до кислоти, моторикою, $\mathrm{F}_{0} \mathrm{~F}_{1}$-АТФазою, реактивними видами кисню та островом патогенності T4SS/Cag, показали підвищену експресію при кислому $\mathrm{pH}$, причому активність деяких генів значно зростала при різних екстремальних значеннях кислотності. Здатність НР відчувати кислотність $\epsilon$ критичною не тільки для активації кислотної акліматизації, але й для стимулювання транскрипції факторів вірулентності, необхідних для колонізації. Вплив кислоти і сечовини $\epsilon$ критичним для всіх аспектів виживання НР у шлунку [4].

HP колонізує слизову оболонку, активує Tollподібні і Nod-подібні рецептори і зазвичай активує шлунковий Т-хелпер 1/17 (Th1/Th17), ініціюючи даний тип імунної відповіді. Складний баланс і між HР та імунними інгібіторними факторами, такими як вакуолізуючий цитотоксин A (VacA), який відповідає за хронічну інфекцію, що локалізується у ніші шлунка. Висвітлено уявлення про уроджені реакції проти HР, а саме нуклеотидзв'язуючий домен олігомеризації, Toll-подібні рецептори епітеліальних клітин шлунка. У деяких інфікованих пацієнтів НP сприяє розвитку автоімунітету шлунка через молекулярну мімікрію між білками НР та аутоантигеном шлункової АТФази. Таким чином, тип імунної відповіді організму людини проти НР має вирішальне значення для результату інфекції [5].

У відповідь на дію НР розвивається запальний процес шлунка, що регулюється рівнями взаємодії між бактерією та організмом людини, які не $\epsilon$ достовірно виявлені під час клітинних взаємодій з гострими патогенами. Через високу захворюваність і смертність від хвороб, викликаних НР, значні зусилля були спрямовані на визначення точних механізмів, за допомогою яких цей патоген викликає запалення шлунка, хоча дані механізми не $\epsilon$ достатньо дослідженими [6]. 
Огляди літератури, оригінальні дослідження, погляд на проблему, ювілеї

Прогресування і тяжкість перебігу гастриту залежать від взаємодії численних факторів:

1 - особливостей НР, включаючи геномну пластичність, здатність адаптуватися до індивідуальних умов господаря, модуляцію реакції на відповідь імунної системи господаря і наявність різних факторів вірулентності;

2 - факторів власне організму людини, наприклад, генетичного фону або фізіологічного та імунологічного стану, особливо тих, які посилюють або зменшують запальні реакції на інфекцію;

3 - факторів навколишнього середовища: куріння, дієти, високого споживання солі та м'яса [7].

Мета - оцінити особливості кислотоутворювальної функції шлунка у хворих на хронічний гастрит (ХГ) та цукровий діабет (ЦД) 2 типу залежно від наявності чи відсутності Helicobacter pylori.

Матеріал і методи. На базі ендокринологічного та гастроентерологічного відділень 3ОКЛ імені А. Новака обстежено 80 пацієнтів, середній вік яких склав $(57,6 \pm 2,3)$ року. Дане дослідження проводили за участі 45 (56,3\%) жінок та 35 (43,7 \%) чоловіків. У всіх пацієнтів діагностовано цукровий діабет 2 типу. Крім того, всі обстежені хворі мали скарги з боку органів травлення (печія, відрижка кислим, важкість та біль в епігастрії). Діагноз ЦД 2 типу встановлено згідно з рекомендаціями International Diabetes Federation (IDF, 2005 р.), тобто визначення рівня глюкози у сироватці крові натще і через 2 год після приймання, що проводили за допомогою глюкозооксидантного методу. Ступінь компенсації діабету оцінювали за рівнем глікозильованого гемоглобіну (НbA1c, \%), який визначали за допомогою хромогенного аналізу на апараті Sysmex 560 (Японія) із використанням реактивів фірми Siemens. Всім пацієнтам проведено фіброгастроезофагодуоденоскопію (ФГДС, з використанням ендоскопа Pentax FG-29», Японія) 3 прицільною біопсією (було взято 5 зразків біопсійного матеріалу зі слизової оболонки шлунка). Дані зразки передано для подальшого гістологічного дослідження. НР визначали, використовуючи швидкий уреазний тест (CLO-test) та тест на наявність антигенів HР в калі (CITO TEST H. Pylori Ag, Pharmasco, Україна).

Кислотоутворювальну функцію шлунка вивчали за допомогою внутрішньошлункової експрес рН-метрії, використовуючи комп'ютерну систему за методом професора Чернобрового. Під час комп'ютерного аналізу результатів звертали увагу на функціональний інтервал $\mathrm{pH}($ (І pH) 0-5 (у напрямку вищої кислотності шлунка):

- $\mathrm{pH} 7,0-7,5$ (ФІ рН0 - анацидність);

- pH 3,6-6,9 (ФІ рН1 - виражена гіпоацидність);

- $\mathrm{pH}$ 2,3-3,5 (ФІ рH2 - помірна гіпоацидність);

- $\mathrm{pH}$ 1,6-2,2 (ФІ рН3 - нормоацидність);
- $\mathrm{pH}$ 1,3-1,5 (ФІ pH4 - помірна гіперацидність); - pH 0,9-1,2 (ФІ рH5 - виражена гіперацидність).

Критерії включення пацієнтів у дане дослідження: підтверджений діагноз ЦД 2 типу та хронічний гастрит.

Критерії виключення пацієнтів із даного дослідження: пацієнти із цД 1 типу; пацієнти, які отримували антигелікобактерну терапію.

Всі дослідження проведено за згодою хворих, а їх методика відповідала Гельсінській декларації 1975 р. та ії перегляду 1983 р.

Наукове дослідження $\epsilon$ фрагментом ДБ теми № 851 «Механізми формування ускладнень при захворюваннях печінки та ПЗ, методи їх лікування та профілактики» (номер державної реєстрації 0115U001103), а також наукової теми кафедри пропедевтики внутрішніх хвороб «Поліморбідна патологія при захворюваннях органів травлення, осо6ливості патогенезу, можливості корекції» (номер державної реєстрації 0118U004365).

Аналіз і обробку результатів обстеження хворих здійснювали за допомогою комп'ютерної програми STATISTICA 6.0 (фірми StatSoftInc, США).

Результати й обговорення. Усіх хворих було поділено на дві групи залежно від інфікування Helicobacter pylori. До I групи увійшли 60 (75\%) осіб, які були НР-позитивними, а другу групу сформовано з 20 (25\%) осіб - НР-негативних хворих на ЦД 2 типу та хронічний гастрит.

Відповідно до даних таблиці 1, у групі НР-позитивних хворих на ЦД 2 типу та ХГ переважали пацієнти з ФІ 0,9-1,2, що відповідає вираженій гіперацидності - 41 пацієнт (68,3 \%), також у 16 осіб із даної групи спостерігали ФІ 1,3-1,5, що відповідає помірній гіперацидності. Тільки у 2 хворих було виявлено ФІ 1,6-2,2 - тобто нормоацидність, і в 1 пацієнта - ФІ 2,3-2,5 - помірну гіпоацидність.

У II групі (НР-негативні хворі на ЦД 2 типу та ХГ) переважали пацієнти з ФІ рH 4, тобто з помірною гіперацидністю - 15 пацієнтів (75 \%), також у 2 (10\%) осіб із даної групи спостерігали ФІ pH5 виражену гіперацидність, та у 2 (10\%) хворих було виявлено ФІ pH 3 - тобто нормоацидність, і в 1 (5 \%) пацієнта - ФІ рH 2 - помірну гіпоацидність.

Отже, беручи до уваги результати даного дослідження, можна стверджувати, що у пацієнтів із цукровим діабету 2 типу та хронічним гастритом залежно від наявності чи відсутності НР виявлено достовірну різницю між кислотоутворювальною функцією шлунка. Тож пацієнти, які $\epsilon$ НР-позитивними, частіше мають порушення кислотоутворювальної функції у вигляді вираженої гіперацидності (68,3\%) порівняно з НР-негативними пацієнтами, серед яких виражену гіперацидність спостерігали тільки в $10 \%$ осіб. Більшість НР-негативних пацієнтів мала помірну гіперацидність (75 \%), по- 
Огляди літератури, оригінальні дослідження, погляд на проблему, ювілеї

Таблиця 1. Зміни кислотоутворювальної функції шлунка у пацієнтів із ЦД 2 типу та ХГ залежно від наявності чи відсутності НР

\begin{tabular}{|c|c|c|}
\hline \multirow[b]{2}{*}{ Кислотоутворювальна функція шлунка } & \multicolumn{2}{|c|}{ Кількість пацієнтів із ЦД 2 типу та ХГ } \\
\hline & $\begin{array}{c}\text { I група } \\
\text { НР-позитивні (60 хворих) }\end{array}$ & $\begin{array}{c}\text { II група } \\
\text { НР-негативні (20 хворих) }\end{array}$ \\
\hline pH 7,0-7,5 (ФІ pH0 - анацидність) & 0 & 0 \\
\hline pH 3,6-6,9 (ФІ pH1 - виражена гіпоацидність) & 0 & 0 \\
\hline pH 2,3-3,5 (ФІ рH2 - помірна гіпоацидність) & $1(1,7 \%)$ & $1(5 \%)$ \\
\hline pH 1,6-2,2 (ФІ pH3 - нормоацидність) & $2(3,3 \%)$ & $2(10 \%)$ \\
\hline pH 1,3-1,5 (ФІ pH4 - помірна гіперацидність) & $16(26,7 \%)$ & $15(75 \%)$ \\
\hline рН 0,9-1,2 (ФІ рН5 - виражена гіперацидність) & $41(68,3 \%)$ & $2(10 \%)$ \\
\hline
\end{tabular}

рівняно з хворими, які були НР-позитивними, де особи з помірною гіперацидністю склали $26,7 \%$ $(p<0,05)$.

Висновки. 1. У більшості хворих на ЦД 2 типу та ХГ при експрес рН-метрії кислотоутворювальної функції шлунка виявлено гіперацидний стан.

\section{ЛІТЕРАТУРА}

1. Moodley, Y. Age of the association between Helicobacter pylori and man / Y. Moodley, B. Linz, R.P. Bond [et al.] // PLoS Pathogens. - 2012. - No. 8 (5).

2. Ansari S. Survival of Helicobacter pylori in gastric acidic territory / S. Ansari, Y. Yamaoka // Helicobacter. 2017. - No. 22 (4). - P. 1-13.

3. Smolka A. J. Helicobacter pylori-induced changes in gastric acid secretion and upper gastrointestinal disease. In Molecular pathogenesis and signal transduction by helicobacter pylori / A. J. Smolka, M. L. Schubert // Springer, Cham. - 2017. - No. 2. - P. 227-252.

4. Marcus E. A. Acid-regulated gene expression of Helicobacter pylori: Insight into acid protection and gastric

\section{REFERENCES}

1. Moodley, Y., Linz, B., Bond, R.P., Nieuwoudt, M., Soodyall, H., Schlebusch, C.M., \& van der Merwe, S.W. (2012). Age of the association between Helicobacter pylori and man. PLoS Pathogens, 8 (5).

2. Ansari, S., \& Yamaoka, Y. (2017). Survival of Helicobacter pylori in gastric acidic territory. Helicobacter, 22 (4), 1-13.

3. Smolka, A.J., \& Schubert, M.L. (2017). Helicobacter pylori-induced changes in gastric acid secretion and upper gastrointestinal disease. In Molecular pathogenesis and signal transduction by helicobacter pylori. Springer, Cham., 2, 227-252.

4. Marcus, E.A., Sachs, G., \& Scott, D.R. (2018). Acidregulated gene expression of Helicobacter pylori: Insight
2. У НР-позитивних пацієнтів частіше виявлено виражену гіперацидність (ФІ 0,9-1,2), а в НР-негативних хворих - помірну гіперацидність (ФІ 1,3-1,5).

Перспективи подальших досліджень. Подальше вивчення особливостей персистування НР у хворих на ЦД 2 типу та ХГ для розробки методики ефективного лікування.

colonization / E. A. Marcus, G. Sachs, D. R. Scott // Helicobacter. - 2018. - No. 23 (3). - P. 1-19.

5. Kaparakis-Liaskos M. Helicobacter pylori: Immune Responses and Gastric Autoimmunity. In the Microbiome in Rheumatic Diseases and Infection / M. Kaparakis-Liaskos, M. M. D'Elios // Springer, Cham. - 2018. - No. 8. - P. 87-96.

6. Israel D. A. Mechanisms of Helicobacter pylori-induced gastric inflammation / D. A. Israel, R. M. Peek // Physiology of the Gastrointestinal Tract. - 2018. - No. 6. P. 1517-1545.

7. Molecular mechanisms of Helicobacter pylori pathogenesis / M. De Falco, A. Lucariello, S. laquinto [et al.] // Journal of Cellular Physiology.-2018.-No. 230 (8).-P. 1702-1707.

into acid protection and gastric colonization. Helicobacter, 23 (3), 1-19.

5. Kaparakis-Liaskos, M., \& D'Elios, M.M. (2018). Helicobacter pylori: Immune Responses and Gastric Autoimmunity. In the Microbiome in Rheumatic Diseases and Infection. Springer, Cham., 8, 87-96.

6. Israel, D.A., \& Peek, R.M. (2018). Mechanisms of Helicobacter pylori-induced gastric inflammation. Physiology of the Gastrointestinal Tract, 6, 1517-1545.

7. De Falco, M., Lucariello, A., Iaquinto, S., Esposito, V., Guerra, G., \& De Luca, A. (2018). Molecular mechanisms of Helicobacter pylori pathogenesis. Journal of Cellular Physiology, 230 (8), 1702-1707. 


\section{ГВУЗ «Ужгородский национальный университет»}

РЕзЮМЕ. Из-за высокой заболеваемости и смертности от болезней, вызванных Helicobacter pylori (HP), значительные усилия были направлены на определение точных механизмов, с помощью которых этот патоген вызывает воспаление желудка, поскольку данные механизмы недостаточно исследованы.

Цель - оценить особенности кислотообразующей функции желудка у больных хроническим гастритом (ХГ) и сахарным диабетом (СД) 2 типа в зависимости от наличия или отсутствия Helicobacter pylori.

Материал и методы. Обследовано 80 пациентов, средний возраст которых составил $(57,6 \pm 2,3)$ года. Данное исследование проводилось с участием 45 (56,3 \%) женщин и 35 (43,7 \%) мужчин. Все больные были поделены на две группы в зависимости от инфицирования Helicobacter pylori. В I группу вошли 60 (75\%) человек, которые были НР-положительными, а вторая группа сформирована из 20 (25 \%) человек - НР-негативных больных СД 2 типа и хроническим гастритом.

Результаты. У пациентов с СД 2 типа и ХГ в зависимости от наличия или отсутствия НР выявлена достоверная разница между кислотообразующей функцией желудка. Поэтому пациенты, которые являются НР-положительными, чаще имели нарушения кислотообразующей функции в виде выраженной гиперацидности (68,3 \%), а пациенты без НР имели умеренную гиперацидность (75 \%).

Вывод. У подавляющего большинства больных СД 2 типа и ХГ при экспресс рН-метрии кислотообразующей функции желудка обнаружено гиперацидное состояние.

КЛЮчЕВЫЕ СЛОВА: сахарный диабет 2 типа; хронический гастрит; Helicobacter pylori.

\section{FEATURES OF ACID-PRODUCTION FUNCTION OF THE STOMACH IN PATIENTS WITH CHRONIC GASTRITIS AND DIABETES MELLITUS TYPE 2 \\ ๑Ye. S. Sirchak, S. V. Patskun \\ Uzhhorod National University}

SUMMARY. Due to the high morbidity and mortality associated with Helicobacter pylori (HP) induced diseases, considerable efforts were made to determine the precise mechanisms by which this pathogen causes stomach inflammation, although these mechanisms are not sufficiently investigated.

The aim of the study - to evaluate the peculiarities of the acid-forming function of the stomach in patients with chronic gastritis (CG) and type 2 diabetes mellitus (DM) depending on the presence or absence of Helicobacter pylori (HP).

Material and Methods. We examined 80 patients with an average age of (57.6 2 2.3) years. This study was conducted with the participation of 45 (56.3\%) women and 35 (43.7 \%) men. All patients were divided into two groups depending on the infection with Helicobacter pylori. The group I included 60 (75\%) people who were HP positive, and the group II included 20 (25\%) people - HP negative patients with type 2 diabetes and chronic gastritis.

Results. Patients with DM type 2 and CG, depending on the presence or absence of HP, found a significant difference between the acid-forming function of the stomach. Therefore, patients who are HP positive are more likely to have an acid-forming function in the form of severe hyperacidity (68.3\%), and patients without HP have moderate hyperacidity (75\%).

Conclusions. In most patients with type 2 diabetes and CG with express pH-metria of acid-forming function of the stomach, hyperacid condition was detected.

KEY WORDS: type 2 diabetes mellitus; chronic gastritis; Helicobacter pylori. 